DOI 10.14746/ssp.2018.3.4

Joanna RAK

Adam Mickiewicz University in Poznań

\title{
From Mobilization to Demobilization: Dynamics of Contention in the Austerity-driven Slovenia ${ }^{1}$
}

\begin{abstract}
The article aims to trace the dynamics of contention in austerity-driven Slovenia, explain why it ended, through the processes of demobilization, despite the protest movement's initial successes, and verify the explanatory power of Charles Tilly and Sidney Tarrow's theoretical framework of demobilization. The analysis applies the method of source analysis, conceptual qualitative content analysis, and the conceptual framework of contentious politics. In doing so, it addresses the research problems of the dynamics of contention in Slovenia and why the contention resulted in demobilization. The article argues that after mass mobilization an upward scale shift appeared. The shift moved the contention beyond its local origins in Maribor, touched on the interests and values of new subjects, and involved a shift of venue to sites where the demands might have been met by state institutions. The dynamics of contention was a cycle of active and passive contentious episodes. The movement identity shift and successful recognition of its claims influenced the performances and episode sequence. The processes of demobilization started when people stopped attending protests, organizing particular performances, and implementing innovations to modular performances instead. Demobilization occurred when most of the protesters became discouraged from protest through boredom and a desire to return to everyday routines.
\end{abstract}

Key words: demobilization, dynamics of contention, collective identity, protest movement, contentious repertoire

\section{Introduction and Methodological Assumptions for the Analysis}

$\mathbf{O}$ n November 2, 2012, a wave of mass protests began in Maribor, Slovenia, and continued until December 31, 2013. In general, the contentious movement which arose shared certain worldviews: increasing

1 This paper is a result of the research project The Culture of Political Violence Dynamics of Anti-austerity Movements in Europe. It was financially supported by the National Science Centre, Poland (grant number 2016/23/D/HS5/00192).

I wish to thank Doctor Džemal Durić (višji policijski inšpektor GPU I) and Danijel Žibret (direktor višji policijski svetnik) for their invaluable professional help in exploring Slovenian contentious politics and providing the data necessary to conduct the research. 
discontent with the governing elites and democracy, as well as a strengthening sense of solidarity (Perković, Učakar, 2017, p. 304). The protests aimed to repeal the austerity measures that had been imposed on the state by the European Central Bank and government (Kirn, 2013; Toplišek, Thomassen, 2017), eradicate corruption and clientelism, and divest the mayor of Maribor, Franc Kangler, the right-wing government leader Janez Janša, and the opposition leader Zoran Janković of public functions on charges of venality (STA, T. M., 2013b). The eventual successful resolution of some of these contentious claims in itself gives little explanation as to why those demanding change stopped doing so at the end of 2013. Firstly, Slovenia did not abandon the austerity measures that were implemented over the crisis in the field of social security payments even in part until January 1, 2018 (Government of the Republic of Slovenia, 2017, p. 30), long after the processes of demobilization (December 31, 2013). Secondly, corruption and clientelism did not subside after 2013 (GAN Integrity, 2015). Thirdly, the contentious activity continued after some of the protesters' goals were achieved. Due to the protests, Kangler stepped down on December 6, 2012 and left office on December 31, 2012 (Media servis, R.I., 2012; Rubin, S. M., 2012). On January 17, 2013, Janković temporarily resigned from his role as president of the Positive Slovenia party (Pozitivna Slovenija) after being accused of corruption in an official report by the Commission for the Prevention of Corruption (Petrovcic, 2015). Janša was subsequently convicted of corruption and sentenced to two years in prison on June 5, 2013 (BBC, 2013). It is worth noting that the protesters stopped making further accusations six months to a year after these personnel changes in the state apparatus.

Although the study of austerity-driven contentious politics is growing, considerably more attention is paid to mobilization than demobilization (Hayes, 2017, p. 22). Current works scrutinize and explain the processes of social appropriation (Baumgarten, 2013, p. 457), boundary activation (Andronikidou, Kovras, 2012, p. 707) and radicalization (Rak, 2017, p. 292; 2018), identify contentious actors (Vobič et al., 2014, p. 77), or focus on performances (Zamponi, González, 2017; D'urso, 2014), repertoires of contention (Ancelovici, 2015, p. 189; Musić, 2013, p. 321), protest policing (Zavratnik, Sori, 2016), and opportunity structures (Sitrin, Azzellini, 2014). They contribute to our understanding of why people begin collective claims-making and pursue contentious politics. Yet we know little about the sources of demobilization in times of austerity, as they remain a largely untouched issue even in specialist literature. 
This article aims to trace the dynamics of contention in austerity-driven Slovenia and explain why it ended through the process of demobilization. The theoretical category of contention allows us to bring together relationships between subjects, objects and claims and compare their changes over time. The research draws on Slovenia instead of any other austerity-driven state because a complete cycle of contention occurred there. Importantly, the case study does not attempt to be representative of the whole Eurozone, but it may serve as a pilot project conducted before implementing a full-scale examination. It also does double duty by describing contentious politics in the state which has been insufficiently studied in the field of anti-austerity movements (Giugni, Grasso, 2015; della Porta, 2015; 2017; Klandermans, van Stekelenburg, 2016; Gerbaudo, 2017). The secondary goal is to verify the explanatory power of Charles Tilly and Sidney Tarrow's theoretical framework of demobilization $(2015$, p. 120). So, the analysis addresses the research problems of the dynamics of contention in post-2008 Slovenia and why the contention ended in demobilization in this case.

According to this theory, after mass mobilization, a process of upward scale shift occurred in Slovenian contentious politics (Tilly, Tarrow, 2015, p. 125). This shift moved the contention beyond its local origins in Maribor, touched on the interests and values of new subjects, and involved a shift of venue to sites where contention was likely to have greater impact, where the objects of the protesters' demands could be threatened (Tilly, Tarrow, 2015, p. 125). The dynamics of contention involved a cycle of contentious episodes, marked by alternate episodes of collective claims-making and lack thereof. The identity shifts and successful expression of claims influenced the performances and episode sequence (Tilly, Tarrow, 2015, pp. 30, 37). Demobilization began when most of the protesters became discouraged, due to repression, boredom, and the desire to return to their normal everyday lives. In such circumstances, the leaders of protest movements can respond in one of two ways; either by the institutionalization of their movement, understood as the progression from disorderly street movements to organized party politics, or by escalation, based on the progressive substitution of more extreme goals and more robust tactics for more moderate ones in order to retain the interest of their supporters and attract new ones (Tilly, Tarrow, 2015, p. 130).

The subject, subject matter, territory, and time aspects of contentious politics establish the research field. The field includes two major contentious actors. Firstly, there are political actors who made anti-austerity 
claims, which led to coordinated efforts based on shared aims, of which the government was a target (Tilly, Tarrow, 2015, p. 7). Secondly, it involves the addressees of the claims, the government. This research is focused on the interactions between these contentious actors between November 2, 2012 and December 31, 2013 in Slovenia in all police units: Celje, Koper, Kranj, Ljubljana, Maribor, Murska Sobota, Nova Gorica, and Novo Mesto. November 2, 2012 is the starting date of the studied period, as this is when the cycle of contention in Slovenia began with mobilization (Durić, Žibret, 2017; Policija, 2013). The closing date is December 31, 2013, when the cycle ended in demobilization (GDELT, $2018 \mathrm{a} ; 2018 \mathrm{~b})$. The dates of mobilization and demobilization determine the time and organizational framework of the contention.

This research period is examined by applying a qualitative method of source analysis. The sources are the Slovenian National Police's report Analiza aktivnosti policije ob protestih na območju Republike Slovenije (Policija, 2013) (in English: Activities of the Police regarding the Protests in the Republic of Slovenia) and the dataset of GDELT Event Database from the GDELT Project data. The search criteria used to generate the dataset were: Start Date $=11 / 02 / 2012$, End Date $=12 / 31 / 2013$, Actor 1 Country: Slovenia, Actor1 Type: all actors, Event Code: 14, Event Quad Class: Event Country: SI, Weighting: NUMEVENTST (GDELT, 2018a; 2018b). The components of the GDELT dataset are PERL, R, and Google BigQuery, which offers a broad spectrum of information from highly diverse Slovenian and international media materials. The triangulation of sources enables the collection of reliable data and helps to avoid following one discourse shaped by given actor of contentious politics.

Conceptual qualitative content analysis enables us to gather sufficient data to trace the dynamics of contention. The analysis makes use of Tilly and Tarrow's research tool for analyzing contentious politics, which consists of concepts and causal relationships between the phenomena described by those concepts (Tilly, Tarrow, 2015, p. 13). The following parts of the article present and employ further methodological and theoretical assumptions in order to solve the research problems.

\section{Dynamics of Contention in Post-2008 Slovenia}

In this study, the period of contention, from mobilization on November 2, 2012 until demobilization on December 31, 2013, is divided into 
fifteen episodes, understood as bounded sequences of continuous interaction (Tilly, Tarrow, 2015, p. 45). This allows us to look at the long streams of contention as a sequence of segments of the collective claimsmaking for the purposes of systematic analysis. The episodes of collective claims-making (active episodes) and those when no claims-making occurred (passive episodes) alternated throughout the cycle of contention (Table 1). The contention brought together the subject (the claimant), the object (the addressee of a claim), and claims themselves (to end austerity measures, extirpate corruption and clientelism, and depose Kangler, Janša, and Janković).

Table 1

Dynamics of Contention in Post-2008 Slovenia

\begin{tabular}{|c|c|c|c|c|c|c|}
\hline No & Episodes & $\mathbf{A}$ & B & Contentious actions & C & D \\
\hline 1 & 2 & 3 & 4 & 5 & 6 & 7 \\
\hline 1 & $\begin{array}{l}\text { Nov. 2, 2012- } \\
\text { Dec. 21, } 2012\end{array}$ & 50 & Yes & $\begin{array}{l}\text { - mass demonstration, } \\
\text { - rally, } \\
\text { - Internet-based call to action, } \\
\text { - charivaris, } \\
\text { - march, } \\
\text { - flower-giving }\end{array}$ & Yes & 52000 \\
\hline 2 & $\begin{array}{l}\text { Dec. 12, } 2012 \\
\text {-Jan. 10, } 2013\end{array}$ & 20 & No & - Internet-based call to action & No & 0 \\
\hline 3 & $\begin{array}{l}\text { Jan. 11, } 2013 \\
- \text { April 1, } 2013\end{array}$ & 81 & Yes & $\begin{array}{l}\text { - mass demonstration, } \\
\text { - rally } \\
\text { - Internet-based call to action, } \\
\text { - charivaris, } \\
\text { - march, } \\
\text { - flower-giving, } \\
\text { - Slovenian Culture Day, } \\
\text { - protestival, } \\
\text { - holy mass of the Trans-Uni- } \\
\text { versal Zombie Church of the } \\
\text { Blissful Ringing }\end{array}$ & Yes & 65000 \\
\hline 4 & $\begin{array}{l}\text { April 2, 2013- } \\
\text { May 15, } 2013\end{array}$ & 44 & No & - Internet-based call to action & No & 0 \\
\hline 5 & $\begin{array}{l}\text { May 16, 2013- } \\
\text { May 18, } 2013\end{array}$ & 3 & Yes & $\begin{array}{l}\text { - mass demonstration, } \\
\text { - Internet-based call to action, } \\
\text { - charivaris }\end{array}$ & No & 30 \\
\hline 6 & \begin{tabular}{|l|} 
May 19, 2013- \\
June 25, 2013
\end{tabular} & 38 & No & - Internet-based call to action & No & 0 \\
\hline 7 & $\begin{array}{l}\text { June 26, 2013- } \\
\text { July 1, 2013 }\end{array}$ & 6 & Yes & $\begin{array}{l}\text { - mass demonstration, } \\
\text { - Internet-based call to action, } \\
\text { - charivaris }\end{array}$ & No & 30 \\
\hline
\end{tabular}




\begin{tabular}{|c|c|c|c|c|c|c|}
\hline 1 & 2 & 3 & 4 & 5 & 6 & 7 \\
\hline 8 & \begin{tabular}{|l} 
July $02,2013-$ \\
July 7,2013
\end{tabular} & 6 & No & - Internet-based call to action & No & 0 \\
\hline 9 & $\begin{array}{l}\text { July 08, 2013- } \\
\text { August 25, 2013 }\end{array}$ & 49 & Yes & $\begin{array}{l}\text { - mass demonstration } \\
\text { - Internet-based call to action } \\
\text { - charivaris }\end{array}$ & No & 30 \\
\hline 10 & $\begin{array}{l}\text { August 26, } 2013 \\
\text {-Sept. 05, } 2013\end{array}$ & 11 & No & - Internet-based call to action & No & 0 \\
\hline 11 & $\begin{array}{l}\text { Sept. 6, 2013- } \\
\text { Sept. 10, } 2013\end{array}$ & 5 & Yes & $\begin{array}{l}\text { - mass demonstration } \\
\text { - Internet-based call to action } \\
\text { - charivaris }\end{array}$ & No & 20 \\
\hline 12 & $\begin{array}{l}\text { Sept. 11, 2013- } \\
\text { Oct. 01, } 2013\end{array}$ & 21 & No & - Internet-based call to action & No & 0 \\
\hline 13 & $\begin{array}{l}\text { Oct. 2, 2013- } \\
\text { Oct. 29, } 2013\end{array}$ & 28 & Yes & $\begin{array}{l}\text { - mass demonstration } \\
\text { - Internet-based call to action } \\
\text { - charivaris }\end{array}$ & No & 20 \\
\hline 14 & $\begin{array}{l}\text { Oct. } 30,2013- \\
\text { Dec. 12. } 2013\end{array}$ & 44 & No & - Internet-based call to action & No & 0 \\
\hline 15 & $\begin{array}{l}\text { Dec. 13, 2013- } \\
\text { Dec. } 31,2013\end{array}$ & 19 & Yes & $\begin{array}{l}\text { - mass demonstration } \\
\text { - Internet-based call to action } \\
\text { - charivaris }\end{array}$ & No & 20 \\
\hline
\end{tabular}

A - Duration of active/passive episode (days);

B - Collective making of claims;

$\mathrm{C}$ - The use of particular performances alongside modular ones;

D - Number of active protesters.

Source: Own study on the basis of the Slovenian National Police's report (Policija, 2013) and the dataset of GDELT Event Database (GDELT, 2018a; 2018b).

The "All-Slovenian People's Uprisings," as the group who began the protests in Maribor were called by the media and by the protesters themselves, mobilized and held protests, with the help of Facebook, blogs, and Twitter (Toplišek, Thomassen, 2017, p. 1390). On November 27, 2012, after spreading to Ljubljana, the protest organized by individuals transformed into a diverse movement including students, lecturers, trade unionists, workers with insecure employment, pensioners, anarchists, ecologists, and socialists (Toplišek, Thomassen, 2017, p. 1390). The event that attracted 52,000 people (Policija, 2013; GDELT 2018a; $2018 b$ ) was coordinated through the movement's General Assembly, supported by smaller coordination groups (Toplišek, Thomassen, 2017, p. 1390). This required mutual communication and the coordination of claims-making (Tilly, Tarrow, 2015, p. 35), which was an important aspect of upward scale shift. 
Following the beginning of mobilization, until December 21, 2012, the protesters (the subject of contention) made claims on various occupy sites, mostly parks, streets, plazas, squares, city centers, and in front of state authority buildings, by modular contentious events: mass demonstrations, rallies, Internet-based calls to action, charivaris (rough music used to make noise and express demands), and marches. Internet-based calls to action helped the claimants during every episode, and were the only type of contentious performance during passive episodes.

During the first episode, a particular contentious performance occurred alongside modular ones. After fierce clashes with the police in December, people made use of flower-giving, which consisted of carrying carnations, handing them to police officers, and attaching them to police uniforms. This performance was intended to demonstrate the protesters' peaceful attitudes toward the police, as the popular slogan stated: "The police are humans like us - we are in this difficult situation together" (Novak, 2013). This action contributed to the image of the contrast between the aggressive police and the peaceful protesters, who simply wished to express their opinion.

Note should be taken that contention spread swiftly across Slovenia and contentious performances took place in seventeen cities, located on the territory of every police unit (Policija, 2013). During the first active episode, the protesters created and popularized a slogan, "Gotof je!/ Gotovi so!" ("He’s finished!/They're finished!") (Toplišek, Thomassen, 2017, p. 1390). The slogan expressed opposition to Janša and the corrupt political elite that had imposed austerity measures on Slovenian society. The process of brokerage consisted of linking the previously unconnected sites. An array of factors led to coordination at a higher level and to the process of upward scale shift. Coordinated action indeed produced knock-on effects, including the development of new alliances between various social groups and attempts by state authorities to tear down offending signs to discredit the protesters (Tilly, Tarrow, 2015, p. 35), e.g., the police removed a 20-meter banner reading "vstaja" ("uprising") from the Ljubljana Castle tower (STA, T. M., 2013a).

As a result of the first episode, Kangler tendered his resignation on December 6, 2012 and left office on December 31, 2012 (Media servis, R.I., 2012; Rubin, S. M., 2012). Thus, the protesters achieved their first success; one of their claims had been met. This reinforced the protesters' confidence in the collective claims-making, gave them confidence for future triumphs, empowered their collective identity, and underpinned 
social bonds between those who felt that their demand had been met due to their collective efforts.

On December 21, 2012, on the Slovenian Democratic Party's (Slovenska demokratska stranka) Twitter profile, protesters were called "communist zombies" led by "the uncles in the background" (political elites from the old regime - J. R.) (M. R., 2012; Gračner, 2013). Over the next contentious episodes, the words "communist" and "uncles" were used as a label for opponents to the austerity policies (Gračner, 2013). Janša failed to discredit the newly created contentious actor and unintentionally contributed to their identity shift and the strengthening of the collective identity of the protesters. Activists reclaimed the label, which was intended to be disrespectful to them, and created a positive symbol of their identity by wearing zombie masks during mass demonstrations and holding cultural performances with zombie puppets. Thus, not only did the statement spark the next round of collective claims-making but also created a powerful leitmotif for the next contentious episode.

Also, the Trans-Universal Zombie Church of the Blissful Ringing was founded in March 2013 and registered in the national registry of religious communities in 2014. The word "zombie" was added to the name after the protesters were called "communist zombies," after a Facebook poll. The church sympathized with the claims of protesters. At this time, according to the founder, it had about 10,000 followers (RT, 2014). This religious initiative empowered the subjects' identity, sense of community, social bonds, and solidarity between individuals.

After Kangler's resignation, which was perceived as success for the Maribor protesters, Slovenians from other cities realized the effectiveness of contentious politics. The third episode lasted from January 11, 2013 to April 1, 2013 and differed from the first in its use of additional particular contentious performances: Slovenian Culture Day, protestivals, and holy masses of the Trans-Universal Zombie Church of the Blissful Ringing organized in front of the National Assembly Building of Slovenia, labelled the "Temple of Corruption." Protestivals aimed to provide people with an opportunity for the cultural expression of political claims through musical performances, physical theatre, puppets, and poetry (Novak, 2013). These innovations in repertories explain the growth in interest in contention and a higher turnout (McAdam, 1983, p. 736). Ordinary people found these particular contentious performances to be a good form of entertainment. Cultural and religious interactive events were a distraction from their routine daily life. 
In the next episode, from December 22, 2012 until January 10, 2013, the protesters abandoned the collective claims-making. The most significant episode started just after the publication of a report by the independent anti-corruption commission in Slovenia on January 9, 2013 (KPK, 2013). The report was critical of Janša and Janković, who were accused of systematic and recurring violations of the law by not properly reporting their assets to the commission and avoiding reporting a private realestate deal with a company that had government contracts (KPK, 2013; Transparency International, 2013). After the report release, more people joined mass demonstrations and the pressure on Janša's coalition partners to leave the government increased (Toplišek, Thomassen, 2017, p. 1392). The protesters wanted Janša and Janković to go the way of Kangler. On January 17, 2013, Janković temporarily stepped down from the role of president of the Positive Slovenia party, due to the allegations by the official Commission for the Prevention of Corruption report (Petrovcic, 2015). After a parliamentary vote of no confidence, Janša was ousted on February 27, 2013, which was considered by the protesters to be a landmark achievement for their collective action (Toplišek, Thomassen, 2017, p. 1392). This time, it was national, rather than local, politicians who were forced to step down. This was a success, but not an incentive to focus on the remaining claims regarding austerity measures, clientelism, and corruption in general.

Following Janša's stepping down as a Prime Minister, after March 20, 2013, the united position of the protesters fell apart. Allen Toplišek and Lasse Thomassen identify and scrutinize the two major paths chosen by activists. Some remained active in local communities and civil society but did not enter into party politics; others created a hybrid political movement to act both on the ground in civil society and through new political parties at the local, national, and European Union levels (Toplišek, Thomassen, 2017, p. 1392). Additionally, Toplišek and Thomassen notice competition over the specific agenda within protest committees themselves and their split into two factions. The first group maintained that all politicians and political parties, regardless of political affiliation, were liable for the prevalence of corruption and clientelism and the state of the economy in Slovenia. The second shared the first group's view but also contended that the protest committee must generate connections with other protest committees and create a new political party in Slovenia (Toplišek, Thomassen, 2017, pp. 1392-1393; Krašovec, 2013). The lack of a sense of common goals was a weakening factor. 
Although diffusion, brokerage, and coordination contributed to the spread of contention actions, they were insufficient to provide the protests with continuity. After the third episode, the number of active protesters fell dramatically from 65,000 between January 11, 2013 and April 1, 2013 to no activity over the fourth episode (GDELT, 2018a; 2018b). There was no collective claims-making between April 2, 2013 and May 15, 2013. After April 2, 2013, turnout ranging from 0 to 30 protesters indicated that the process of demobilization was underway.

Collective claims-making was revived briefly between May 16-18, 2013, but it only attracted about 30 activists (GDELT, 2018a; 2018b). Starting with this episode, each of the following active episodes had the same set of modular performances: mass demonstrations, Internet-based calls to action, and charivaris. No particular performances were held, which indicated the routinization of repertoire and a decrease in instigative innovations.

The sixth episode lasted from May 19, 2013 until June 25, 2013 and was marked by no collective claims-making. In this period, however, Janša was convicted of corruption and sentenced to two years in prison on June 5, 2013 (BBC, 2013). The protesters had no reason for renewing claims on this politician. There were still active episodes, because two other substantial claims remained unsatisfied. However, these contentious performances had a low turnout, which shows that the movement was not strong enough to make claims effectively. There was no significant event that affected contentious politics over the following episodes. The next active episode took place from June 26, 2013 until July 1, 2013 and involved 30 protesters (GDELT, 2018a; 2018b). This episode was followed by a fleeting passive episode from July 2, 2013 until July 7, 2013. The ninth episode was of an active nature and lasted from July 8, 2013 until August 25, 2013. As in the seventh episode, the turnout was around 30 people (GDELT, 2018a; 2018b). From August 26, 2013 until September 5,2013 , no collective claims-making took place. An active episode took place between September 6, 2013 and September 10, 2013. The attendance was slightly lower than during the ninth episode and totaled 20 protesters (GDELT, 2018a; 2018b). A passive episode occurred from September 11, 2013 until October 1, 2013. The collective claims-making began again October 2, 2013 and continued until October 29, 2013. Turnout was as low as over the previous active episode (GDELT, 2018a; 2018b). The last passive episode before demobilization lasted from October 30, 2013 until December 12, 2013. The episode of the collective 
claims-making that lasted from December 13, 2013 until December 31, 2013 preceded demobilization. The last wave of protests failed to attract more than 20 people (GDELT, 2018a; 2018b).

Competition over the agenda, which substantially exhausted the protesters, continued into the subsequent institutionalization of the protest movement into party politics. On December 14, 2013, the protesters set up a new political party, Solidarity (Solidarnost). In 2014, Solidarity became a coalition partner for the Social Democrats (Socialni demokrati), the object of their claims during the protests, in the campaign for the Republic of Slovenia Early Elections to the National Assembly, but won no seats (Toplišek, Thomassen, 2017, p. 1393). It also won no seats in the European parliamentary election, receiving just $1.66 \%$ of the vote (EP, 2014). More successful was the Initiative for Democratic Socialism (Iniciativa za demokratični socializem) formed on March 8, 2014 by other protesters (Mo. B., Delo.si, STA, 2014). The Initiative for Democratic Socialism joined the United Left (Združena levica) and, in 2014, received $5.97 \%$ of the vote in the Slovenian parliamentary election, thus receiving 6 seats together (Ministry of the Interior, 2014). The Initiative for Democratic Socialism won $5.47 \%$ of the vote in the European Parliament election and failed to win a seat (EP, 2014).

\section{Conclusion: Processes of the 2013 Demobilization in Slovenia}

This part of the article applies Tilly and Tarrow's explanatory framework of demobilization to capture and account for the processes that ended the cycle of contention in Slovenia. Analysis of the dynamics of contention shows that the process of demobilization began after the third contentious episode.

Tilly and Tarrow argue that mobilization is "an increase of the resources available to a political actor for collective making of claims" (2015, p. 120). They consider mobilization the opposite of demobilization, defined as "a reduction of this aggregation of resources" (Tilly, Tarrow, 2015, pp. 120,127). According to Tilly and Tarrow, the course and rate of demobilization depend on the initial conditions of mobilization, the strategy of elites and authorities in response to the makers of claims, and on the degree to which the protesters develop enduring structures to maintain their solidarity $(2015, \mathrm{p}$. 127). In Slovenia, the process of demobilization occurred after the achievement of the goals that were the easiest 
to attain. The protesters were successful in achieving personnel changes at local (Kangler) and national (Janša and Janković) levels in the state apparatus. They settled for these cosmetic changes and lost momentum to pursue the remaining claims that were much more difficult to achieve, but which would be of greater importance for the political structure's effectiveness. The object was fulfilling the claims in stages until the collective making of claims was intense. As a result, no significant changes in political elites took place and austerity measures remained unchanged.

In the period from mobilization to demobilization, the protesters maintained solidarity until after the third contentious episode. The label "zombie" was meant to discredit the protesters but contributed to their collective identity and marked successful particular contentious performances. Slovenian Culture Day, protestivals, and holy masses organized by the Trans-Universal Zombie Church of the Blissful Ringing attracted many ordinary people who strived to spend their free time in a novel way. The religious and cultural programs grabbed the attention of Slovenians for several weeks, and then quickly lost their novelty value.

Tilly and Tarrow argue that demobilization occurs when most of the protesters become discouraged by repression, boredom, and the desire to return to their normal lives. In Slovenia, however, repression was not a factor that influenced demobilization. The media did not present protest policing as illegitimate, and there were no complaints about the detention order (Policija, 2013; Maza, 2013). The extent of social legitimation of police behavior by participants in the protests was very high. The modular performance of flower-giving reveals that the protesters avoided opposing the police.

Nonetheless, boredom and the desire to go 'back to normal' were observed after a relatively short period of avid interest in particular contentious performances (Perković, Učakar, 2017, p. 304). Their potential for entertainment inevitably ran out when they became a part of routine daily life. The protesters avoided developing further novel actions so as to focus on the further collective making of claims and thus they let their mobilization potential drain.

Tilly and Tarrow assume that the leaders respond to the process of the protesters losing momentum in one of two antonymic ways. Firstly, institutionalization occurs, which involves "the substitution of the routines of organized politics for the disorder of life in the streets, buttressed by a mass organization and purposive incentive" (Tilly, Tarrow, 2015, p. 130). Indeed, there were some attempts to institutionalize the protesters 
but internal competition precluded this. This meant that, in Slovenia, attempts at institutionalization following demobilization were unsuccessful. The protest movement had no resources to renew the collective making of claims. Secondly, according to Tilly and Tarrow, the leaders responded by escalation, which is "the substitution of more extreme goals and more robust tactics for more moderate ones in order to maintain the interest of their supporters and attract new ones" (Tilly, Tarrow, 2015, p. 130). The escalation that occurred in the party political programs which followed the protests failed to retain wavering or attract new supporters, which the election results clearly demonstrate.

\section{Bibliography}

Ancelovici M. (2015), Crisis and Contention in Europe: A Political Process Account of Anti-Austerity Protests, in: Europe's Prolonged Crisis, eds. H. J. Trenz, C. Ruzza, V. Guiraudon, London.

Andronikidou A., Kovras, I. (2012), Cultures of Rioting and Anti-Systemic Politics in Southern Europe, "West European Politics," vol. 35, no. 4.

Baumgarten B. (2013), Geração à Rasca and Beyond: Mobilizations in Portugal After 12 March 2011, "Current Sociology," vol. 61, no. 4.

BBC (2013), Ex-Slovenian PM Janez Jansa convicted of corruption, 5.06.2013, "BBC," http://www.bbc.com/news/world-europe-22781752, 23.02.2018.

della Porta D. (2015), Social Movements in Times of Austerity: Bringing Capitalism Back Into Protest Analysis, Cambridge.

della Porta D. (2017), Late Neoliberalism and Its Discontents: A Comparative Conclusion, in: Late Neoliberalism and its Discontents in the Economic Crisis: Comparing Social Movements in the European Periphery, eds. D. della Porta, M. Andretta, T. Fernandes, F. O'Connor, E. Romanos, M. Vogiatzoglou, Cham.

Durić D., Žibret D. (2017), Respond to query 630-36/2017/4: Slovenian National Police. Register: 630-36/2017/4(262-03) [in the author's records].

D'urso S. (2014), The Affirmation of 'Life' Beyond Governance: Performance art that resists citizenship under austerity, "Performance Research," vol. 19, no. 2.

EP (2014), Results of the 2014 European elections: Slovenia, "European Parliament," http://www.europarl.europa.eu/elections2014-results/en/country-resultssi-2014.html, 27.02.2018.

GAN Integrity (2015), Slovenia Corruption Report, https://www.business-anti-corruption.com/country-profiles/slovenia\#, 23.02.2018.

GDELT (2018a), GDELT EVENT Timeline results for Slovenia, http://data.gdeltproject.org/analytics_user/20180208223031.20615.timeline.pn, 8.02.2018. 
GDELT (2018b), GDELT List of events for Slovenia, http://data.gdeltproject.org/analytics_user/20180208223031.20615.csv, 8.02.2018.

Gerbaudo P. (2017), The indignant citizen: anti-austerity movements in southern Europe and the anti-oligarchic reclaiming of citizenship, "Social Movement Studies," vol. 16, no. 1.

Giugni M., Grasso, M. T. (eds.) (2015), Austerity and Protest: Popular Contention in Times of Crisis, New York.

Government of the Republic of Slovenia (2017), Draft budgetary plan 2018. Sector for public finance analyses and coordination of economic policy, http://www.

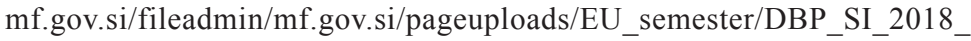
popravljeno_f.pdf, 23.02.2018.

Gračner B. (2013), Slovenia's 'Zombie uprising, 1.03.2013, “Counterfire,” http://www. counterfire.org/international/16323-slovenias-zombie-uprising, 27.02.2018.

Hayes G. (2017), Regimes of austerity, "Social Movement Studies,” vol. 16, no. 1.

Kirn G. (2013), Social Uprising in Slovenia against Neoliberal Austerity Measures, 25.02.2013, "Global Research," https:/www.globalresearch.ca/social-uprising-in-slovenia-against-neoliberal-austerity-measures/5324218, 23.02.2018.

Klandermans B., van Stekelenburg J. (2016), Taking Austerity to the Streets: Fighting Austerity Measures or Austerity States, "Mobilization: An International Quarterly," vol. 21, no. 4.

KPK (2013), KPK: odziv na nekatera vprašanja po včerajšnji objavi Zaključnega poročila nadzora nad premoženjskim stanjem predsednikov parlamentarnih strank, 9.01.2013, https://www.kpk-rs.si/s1/komisija/medijsko-sredisce/ arhiv-novic/1/2013/kpk-odziv-na-nekatera-vprasanja-po-vcerajsnji-objavizakljucnega-porocila-nadzora-nad-premozenjskim-stanjem-predsednikovparlamentarnih-strank, 25.02.2018.

Krašovec P. (2013), The Slovenian Uprising in Retrospect, "Debatte: Journal of Contemporary Central and Eastern Europe," vol. 21, no. 2-3.

Maza C. (2013), Rough guide to Slovenian protests, 2012/2013, 4.02.2013, "Cafebabel," http://www.cafebabel.co.uk/society/article/rough-guide-to-slovenianprotests-20122013.html. 2.03.2018.

Media servis, R. I. (2012), Prosvjedi su uspjeli: Mariborski gradonačelnik podnosi ostavku!, 6.12.2012, "Index," http://www.index.hr/vijesti/clanak/prosvjedi-su-uspjeli-mariborski-gradonacelnik-podnosi-ostavku/650781.aspx, 23.02.2018.

McAdam D. (1983), Tactical Innovation and the Pace of Insurgency, "American Sociological Review," vol. 48, no. 6.

M. R. (2013), SDS na Twitterju: Vstaja zombijev, ne pa vstaja naroda, 21.12.2012, "24ur.com," http://www.24ur.com/novice/slovenija/janseva-stranka-ne-vidiprotestnikov-temvec-zombije.html, 27.02.2018.

Ministry of the Interior (2014), Republic of Slovenia Early elections for deputies to the National Assembly 2014, 13.07.2014, "Republic of Slovenia State Elec- 
tion Committee," http://volitve.gov.si/dz2014/en/rezultati/rezultati_slo.html, 27.02.2018.

Mo. B., Delo.si, STA (2014), Nastala je nova stranka, Iniciativa za demokratični socializem, 8.03.3014, "Delo," http://www.delo.si/novice/politika/nastala-jenova-stranka-iniciativa-za-demokraticni-socializem.html, 27.02.2018.

Musić G. (2013), Between Facebook and the Picket Line: Street Protests, Labour Strikes and the New Left in the Balkans, "Debatte: Journal of Contemporary Central and Eastern Europe," vol. 21, no. 2-3.

Novak M. (2013), Slovenia rises in artful "protestivals”, 21.03.2013, "Waging nonviolence," https:/wagingnonviolence.org/feature/slovenia-rises-in-artfulprotest/, 27.02.2018.

Perković A. J., Učakar T. (2017), Economic crisis and the crisis of national identity in Slovenia: toward a new notion of social order, "Nationalities Papers: The Journal of Nationalism and Ethnicity," vol. 45, no. 2.

Petrovcic U. (2015), Constitutional Change Through Euro Crisis Law: "Slovenia", 26.01.2015, "European University Institute," http://eurocrisislaw.eui.eu/country/slovenia/topic/political-context/, 23.02.2018.

Policija (2013), Analiza aktivnosti policije ob protestih na območju Republike Slovenije [in the author's records].

Rak J. (2017), Intrastate, Regional, and Colonial Contributions to Post-2008 Cultures of Political Violence, "Polish Political Science Yearbook," vol. 46, no. 1.

Rak J. (2018), Theorizing Cultures of Political Violence in Times of Austerity: Studying Social Movements in Comparative Perspective, New York.

RT (2014), "In the name of the Holy Pot": Zombie Church preaches against corruption in Slovenia, 24.12.2014, "RT," https:/www.rt.com/news/217235-slovenia-zombie-church-corruption/, 26.02.2018.

Rubin M., S. M. (2012), Kangler uradno odstopil: mandat bo končal 31. decembra, 6.12.2012, "Delo," http://www.delo.si/novice/slovenija/kangler-uradnoodstopil-mandat-bo-koncal-31-decembra.html, 23.02.2018.

Sitrin M., Azzellini D. (2014), They Can't Represent Us! Reinventing Democracy from Greece to Occupy, New York.

STA, T. M. (2013a), “All-Slovenian Uprising” With the Lack of Protesters, 9.03.2013, "The Slovenia Times," http://www.sloveniatimes.com/all-slovenian-uprisingwith-the-lack-of-protesters, 27.02.2018.

STA, T. M. (2013b), Public Opinion: Janković and Janša Must Resign, 21.01.2013, "The Slovenia Times," http://www.sloveniatimes.com/public-opinion-jankovic-and-jansa-must-resign, 23.02.2018.

Tilly Ch., Tarrow S. (2015), Contentious Politics, 2nd edition, New York.

Toplišek A., Thomassen L. (2017), From Protest to Party: Horizontality and Verticality on the Slovenian Left, "Europe-Asia Studies," vol. 69, no. 9.

Transparency International (2013), Holding Politicians to Account: Slovenia's Prime Minister Ousted, 4.03.2013, "Transparency International," https:/www.trans- 
parency.org/news/feature/holding_politicians_to_account_slovenias_prime_ minister_ousted, 25.02.2018.

Vobič I., Sašo A., Brlek S., Mance B., Prodnik J. A. (2014), Changing Faces of Slovenia: Political, Socio-Economic and News Media Aspects of the Crisis, "Javnost - The Public Journal of the European Institute for Communication and Culture," vol. 21, no. 4.

Zamponi L., González J. F. (2017), Dissenting youth: how student and youth struggles helped shape anti-austerity mobilisations in Southern Europe, "Social Movement Studies," vol. 21, no. 4.

Zavratnik S., Sori I. (2016), Od »nesimo jih vun!« k zamolku ulice: diskusija o kriminalizaciji uporov in premiku $k$ druzbi nadzora, "Druzboslovne Razprave," vol. 32 , no. 82 .

\section{Od mobilizacji do demobilizacji: dynamika konfliktu w Słowenii w okresie wychodzenia z kryzysu ekonomicznego}

\section{Streszczenie}

Celami artykułu są: przeanalizowanie dynamiki konfliktu, który wystapił w Słowenii w okresie wychodzenia z kryzysu ekonomicznego, wyjaśnienie, dlaczego pomimo początkowych sukcesów ruchu protestu konflikt zakończył się procesami demobilizacji oraz zweryfikowanie mocy eksplanacyjnej modelu teoretycznego demobilizacji autorstwa Charlesa Tilly’ego i Sidney’a Tarrowa. Badanie wykorzystuje metodę analizy źródeł, jakościową konceptualną analizę treści i siatkę kategorialną teorii konfliktu do rozwiązania problemów badawczych: jaka była dynamika konfliktu w Słowenii? I dlaczego konflikt zakończył się demobilizacją? Studium pokazuje, że po okresie masowej mobilizacji doszło do zwiększenia skali protestów. Zmiana ta polegała na rozprzestrzenieniu konfliktu poza Maribor, czyli obszar jego powstania, zaangażowaniu nowych podmiotów politycznych za sprawą wspólnoty interesów i wartości, rozszerzeniu spektrum miejsc publicznych, które mogły służyć domaganiu się realizacji żądań prowadzącemu do ich zaspokojenia przez podmioty państwowe. Dynamikę konfliktu wyznaczyły jego aktywne i bierne epizody. Zmiana tożsamości ruchu i zakończone sukcesem rozpoznanie żądań zdeterminowały wykorzystanie różnych typów protestu i serię epizodów. Procesy demobilizacji rozpoczęły się, gdy dotychczasowi aktywiści przestali uczestniczyć w protestach, zaniechali organizowania specjalnych wydarzeń i wdrażania innowacji w modułowych akcjach. Demobilizacja nastąpiła wraz z rezygnacją większości zaangażowanych w działalność ruchu z protestowania z powodów znudzenia tą formą aktywności politycznej i pragnienia powrotu do rutyny codzienności.

Słowa kluczowe: demobilizacja, dynamika konfliktu, tożsamość zbiorowa, ruch protestu, repertuar konfliktu 